\title{
Viability of Distributed Generation with Biogas and Photovoltaic in an Isolated System
}

\author{
Effrain Roney Bernardes ${ }^{* *}$ and José Roberto Camacho*1 \\ ${ }^{1}$ School of Electrical Engineering \\ Universidade Federal de Uberlândia \\ Campus Santa Mônica, 38400-902, Uberlândia - MG (Brazil) \\ Phone/Fax number:+55.34 999.712.710, e-mail: "jrcamacho@ufu.br, ${ }^{* *}$ effrainroney@gmail.com
}

\begin{abstract}
.
In the 1970s, the Brazilian oil crisis sparked interest in researching inexhaustible sources of energy. Within these sources of energy, those known as clean and abundant have become a viable alternative, reducing the pollutant capacity of waste, because the gas emitted by them in the decomposition that would previously go to the environment, is now destined for energy production and solid portion used as organic fertilizer [5]. This work aims to implement a case study to estimate the economic viability of the project, hybrid sources, in rural areas. The project in question will be analysed through software and mathematical methods, guaranteeing results close to those calculated analytically, compared to the energy sources studied as well as their feasibility and profitability through isolated distributed generation, which can bring fast and safe returns, such as a return of $84.37 \%$ biogas and $77.76 \%$ for photovoltaic compared to the initial investment over 25 years. Currently, Brazil suffers from a shortage of rainfall and consequently, with problems in the energy matrix, since the majority of Brazilian electricity comes from a hydroelectric power plant. Therefore, the purpose of this study is to present a solution and consequently self-sufficiency in rural areas, taking advantage of biodigesters and abundant sun to produce electricity.
\end{abstract}

\section{Key words}

Photovoltaic; Biogas; Biodigester; Distributed generation; Payback

\section{Introduction}

Energy is an indispensable asset to the existence of any living being. Among its final forms, electricity is one of the most used, and although present in the lives of many, it does not cover all people. The search for the universalization of electric service is a constant challenge faced by ordinary citizens, authorities, governments and other segments of society. One of the main reasons for the absence of electric energy in the lives of thousands of people in the world is the condition of poverty allied with the situation of geographic isolation in which they find themselves. Although still critical, this panorama has been changing over time. Advances in the research and development of alternative energy sources based on renewable sources, together with government and social programs, mainly concerned with the exclusion caused by the absence of electricity and the growing environmental problems, have been responsible for profound and important changes. Countries such as Germany, Spain and the United States already have great penetration of renewable energies in their energy matrices. At the national level, government programs like Proinfa and Light for All are major incentives for the development of studies aimed at making renewable sources even more competitive. The expansion of electric service in Brazil, as in many other countries of the world, is basically through the extension of transmission lines belonging to the interconnected system, or through the small, medium and even large thermal generation, usually with the use of generator sets with fuel of fossil origin, mainly diesel oil. The first is a viable solution when the transmission / distribution system is not too far from the consumer center to be served, or when it is of sufficient size to represent economic attractiveness to the power authority. The second has its greatest attractions in the relative ease of acquisition, installation and use, in addition to the low initial cost. Such solutions, however, do not constitute a single option. On the contrary, the accelerated technical growth of renewable sources has made them competitive, and many times more viable than the so-called conventional sources. Renewable systems, whose primary sources are solar photovoltaic and wind, are among the most considered options currently, although there is also the possibility of using biomass systems and (SHPs) small hydro power plants. In the current context of Brazil's energy scenario, alternative sources of energy have been highlighted to fill the gap. However, mainly in rural areas where high quality energy is difficult to access, through investment, rural producers are using these new sources of energy.

According to the regulators, animal production is one of the activities with the greatest environmental impact, considered by these as one of the main causes of degradation, with a great potential polluter with respect to water resources. Following this line, the need arose to create biodigesters to collect animal waste, and, through this, to use methane, derived from the decomposition of organic matter, for the generation of electric energy. On 
the other hand, there has always been an inexhaustible source of energy, the Sun, using this raw material as well, to generate electricity through the photovoltaic effect. With the normative resolutions of ANEEL 482, the distributed generation system became highly profitable, since these standards help in the forms of compensation, thus bringing greater viability. In the midst of the technological conjuncture and the scientific advances that propitiate the advent of new computational tools, software are often developed with the purpose of simplifying the resolution of problems and of guaranteeing greater reliability in the results. The PVsyst program with a $2 \mathrm{D}$ interface has the following objectives: to combine a theoretical method in the resolution of problems related to engineering, in particular to electrical engineering, such as: shading, quantities of photovoltaic modules, inverters, cabling and economic viability. Its interface brings the necessary tools to estimate the amount needed to meet demand and check for shading or other factors that may bring future problems for electricity generation. The PVsyst program has gained considerable space, both in academic and industrial areas.

\section{Distributed Generation Modelling}

Hybrid energy systems incorporate various types of electricity generating components with generally a main control system that allows the system to provide quality electricity. A typical hybrid system combines two or more sources, from renewable energy technologies such as photovoltaic panels, wind turbines or small hydraulic turbines; and conventional technologies, usually diesel or LPG generators (although biomass-fuelled generator sets are also a viable option, if available locally). In addition, it includes power electronics and storage batteries for electricity. The hybrid system can be designed in different configurations to effectively use locally available renewable energy sources and to serve power appliances (requiring DC or AC electricity) [3]. This result in a large reduction in fuel consumption compared to the system which is powered only by genset. [9.10] Advanced search in automation and control of the hybrid power system has made it popular to the world and has encouraged researchers to use different types of renewable sources to reduce the demand for energy sources. [13] In the hybrid system components proposed for electricity, renewable energy sources such as wind, solar and biogas are used.

\section{A. Sizing and Topology of the Hybrid Generation}

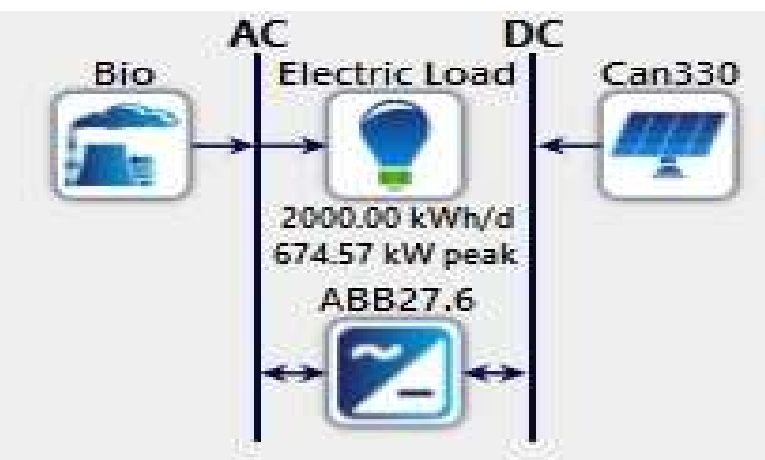

Fig. 1. Flow diagram of the hybrid generation deployment, Homer software with biogas and photovoltaic.
The modelling of the hybrid system will be according to figure 1 , to determine the power that is needed to meet the destination load, the following equation (1) is used.

$$
P_{l d}=P P_{l d}+B P_{l d}
$$

Where:

$\boldsymbol{P}_{\boldsymbol{l d}}=$ Load demand (kVA);

$\boldsymbol{P P}_{\boldsymbol{l d}}=$ Peak load power demand (kVA);

$\boldsymbol{B} \boldsymbol{P}_{\boldsymbol{l d}}=$ Power of the grid respectively (kVA).

\section{B. Biodigesters Sizing}

We chose the Canadian biodigester model. Firstly, the biodigester system adopted is a horizontal type model, presenting a masonry load box with a width greater than the depth, thus having a larger area of exposure to the sun, which allows a large production of biogas and avoiding clogging. During the production of gas, the dome of the biodigester inflates because it is made of soft plastic material (PVC) and can be removed [12]. The daily production of $2.1 \mathrm{~kg} /$ animal.day $\left(0.0021 \mathrm{~m}^{3} / \mathrm{d}\right)$ was considered to be finished in the finishing phase[7] and the hydraulic retention time (HRT) of 30 days [1]. Calculation of the volume of the adapted biodigester, according to equation (2).

$$
V_{b}=V_{d} . T R H . N A
$$

Where:

$\boldsymbol{V}_{\boldsymbol{b}}=$ volume of biodigester $\left(\mathrm{m}^{3}\right)$;

$\boldsymbol{V}_{\boldsymbol{d}}=$ daily volume of waste ( $\mathrm{m}^{3} /$ animal day);

$\boldsymbol{T} \boldsymbol{R} \boldsymbol{H}=$ hydraulic retention time (days);

$\boldsymbol{N A}=$ number of animals

The data referring to values of the bio digestion system compose the costs of the biogas, obtained through the following equation (3).

$$
C_{b}=\frac{C_{B}}{p_{b} \cdot t}
$$

Where:

$\boldsymbol{C}_{\boldsymbol{b}}=$ cost of biogas $\left(\mathrm{R} \$ / \mathrm{m}^{3}\right)$;

$\boldsymbol{C}_{\boldsymbol{B}}=$ biodigester cost $(\mathrm{R} \$)$;

$\boldsymbol{p}_{\boldsymbol{b}}=$ production of biogas $\left(\mathrm{m}^{3} /\right.$ year $)$;

$\boldsymbol{t}=$ biodigester useful life (years).

Table I. - Organic matter data
\begin{tabular}{|l|c|}
\hline \multicolumn{2}{|c|}{ Biogas } \\
\hline Biogas / animal production / Day & $2.1 \mathrm{Nm}^{3} / \mathrm{d}$ \\
\hline Estimated biogas production / day & $210 \mathrm{Nm}^{3} / \mathrm{d}$ \\
\hline Generator set consumption $80 \mathrm{kVA}$ & $35 \mathrm{Nm}^{3} / \mathrm{h}$ \\
\hline $\begin{array}{l}\text { Estimated Kw/H Generation } 80 \mathrm{kVa} \\
\text { Generator }\end{array}$ & $55 \mathrm{~kW} / \mathrm{h}$ \\
\hline Estimated work time & $6 \mathrm{Hrs} /$ day \\
\hline Total generated estimated day & $330 \mathrm{~kW} / \mathrm{h} /$ day \\
\hline Estimated cost kW / h & $0.53 \mathrm{R} \$ / \mathrm{h}$ \\
\hline Total generated estimated day / R\$ & $174.90 \mathrm{R} \$ /$ day \\
\hline Total generated estimated month / R $\$$ & $5,247.00 \mathrm{R} \$ / \mathrm{month}$ \\
\hline
\end{tabular}


For the dimensioning of the organic matter quantity, the data of table I will be used, considering the free stall regime to obtain the results, according to figure 2 , the volume of the biodigester will be $800 \mathrm{~m}^{3}$.

Figure 2 depicts a free-stall regime, where cattle are confined to separate sites increasing capture of animal waste.

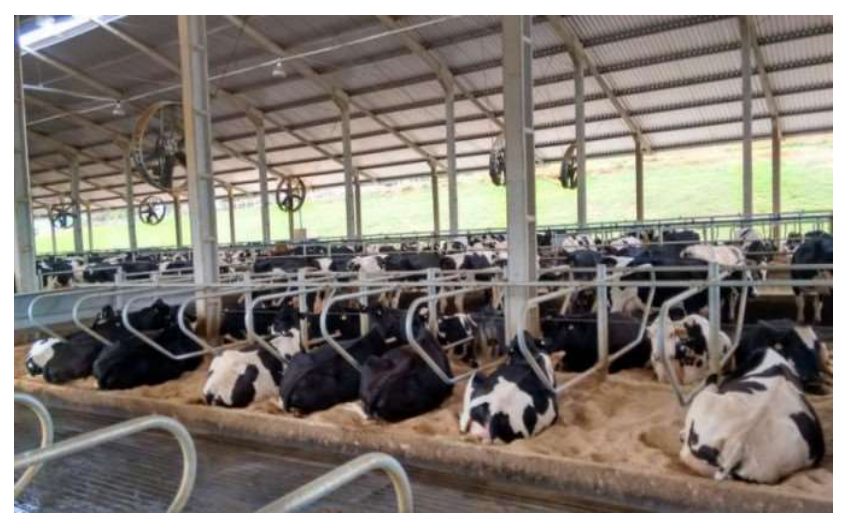

Fig.2.Free-stall style confined cattle image (source:// http://iepec.com/com-producao-de-leite-em-regime-free-stallparanaense-e-exemplo-de-empreendorismo-em-goias/).

\section{Sizing of the Biogas Generator}

For the design of the generator motor, it is necessary to use the parameters of table I and table II, the calorific value of the biogas, the efficiency of the generator motor, the daily availability of biogas next to each of the agroindustry units $\left(\mathrm{m}^{3}\right.$.day) and the time of use of the generation plant. Knowing the calorific power of biogas, it is possible to quantify the electric energy generated by cubic meter of biogas. This quantification can be obtained by means of:

$$
P T E=P C I . P B
$$

Where:

$\boldsymbol{P T E}=$ is the potential for electricity production

(kWh.day);

$\boldsymbol{P C I}=$ is the calorific value (kWh.month);

$\boldsymbol{P} \boldsymbol{B}=$ is the annual production of biogas ( $\mathrm{m}^{3}$.day).

The size of the biogas will be used according to table II, with a generator of $80 \mathrm{kVA}$ working 6 to 8 hours per day, with an estimated production of $59,400 \mathrm{kWh} /$ month. In order to determine the technical potential of electricity production, account should be taken of the overall conversion efficiency of thermal machines (generator set, gas microturbine, etc.). Thus, for the purpose of a more precise estimate, the value to be adopted is $25 \%$ [11].

The technical potential of energy generation is calculated by:

$$
P T C E=\frac{P T E . n}{100}
$$

Where:
$\boldsymbol{P T C E}=$ technical potential of energy generation $(\mathrm{kWh} /$ day);

$\boldsymbol{P T} \boldsymbol{E}=$ theoretical potential of electric energy production (kWh / day);

$\boldsymbol{n}=$ conversion efficiency.

Table II. - Biogas Contact info

\begin{tabular}{|l|c|}
\hline \multicolumn{2}{|c|}{ Organic matter } \\
\hline Production Animal / Day / Day & $200 \mathrm{~L}$ \\
\hline Total Production Day & $20,000 \mathrm{~L}$ \\
\hline Total in month treatment & $800 \mathrm{~m}^{3}$ \\
\hline Compound/animal production/day & $30 \mathrm{Kg} / \mathrm{d}$ \\
\hline Estimated compound production/day & $1,650 \mathrm{Kg} / \mathrm{d}$ \\
\hline $\begin{array}{l}\text { Estimated composite production/ } \\
\text { month }\end{array}$ & 49,500 \\
\hline Biofertilizer production/animal/day & $120 \mathrm{Lt} / \mathrm{d}$ \\
\hline $\begin{array}{l}\text { Estimated biofertilizer production/ } \\
\text { day }\end{array}$ & $12,000 \mathrm{Lt} / \mathrm{d}$ \\
\hline $\begin{array}{l}\text { Estimated biofertilizer production/ } \\
\text { month }\end{array}$ & 360,000 \\
\hline Potential in revenue - compound & $\mathrm{Lt} / \mathrm{month}$ \\
\hline Potential in revenue - biofertilizer & $3,960.00$ \\
& $\mathrm{R} \$ / \mathrm{month}$ \\
\hline
\end{tabular}

The calculation of the electric power of the generation plant is obtained through equation (6).

$$
P O T=\frac{P T C E}{H O \cdot \cos \varphi}
$$

Where:

$\boldsymbol{P O T}=$ electric potential of the generation plant $(\mathrm{kVA})$; $\boldsymbol{H O}=$ number of hours of daily engine operation (hours); $\cos \boldsymbol{\varphi}=$ power factor.

\section{Photovoltaic Sizing}

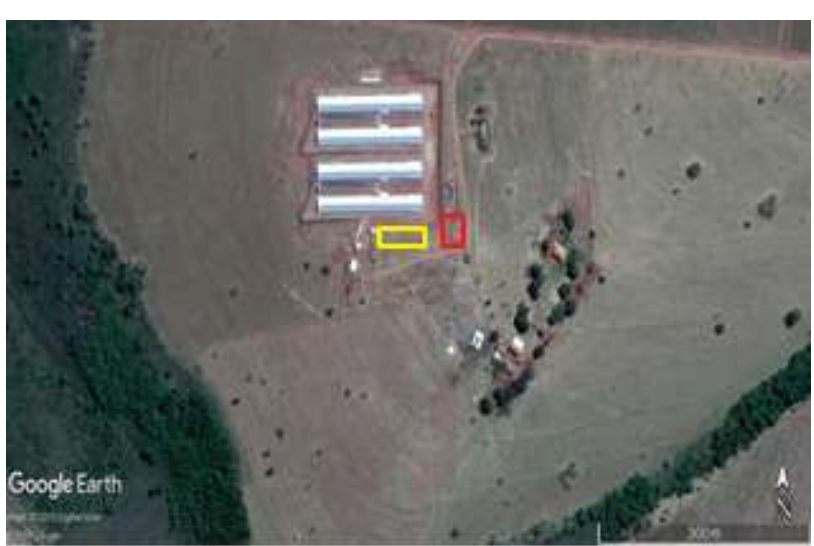

Fig. 3. Satellite image of the farm Sabiá (source: \\google.maps).

Figure 3 shows Fazenda Sabiá, with a three-phase rural system, with voltage of $380 \mathrm{~V} / 220 \mathrm{~V}$, with substation type station 1, with a transformer of $112.5 \mathrm{kVA}$. In this establishment, the monthly consumption is $16,359.75$ $\mathrm{kWh} /$ month during the year, being that it consists of a chicken farm for export with use of refrigeration for the animals and constant feed for chicken fattening, in the left 
box is where the photovoltaic modules were installed and the biodigester system is in the left box.

For the sizing of the photovoltaic system, it was taking into account some factors, firstly it is necessary to use some formulas to calculate the power of the project to be build. One of the main factors to be correctly estimated is the irradiation of the region where the project was installed.

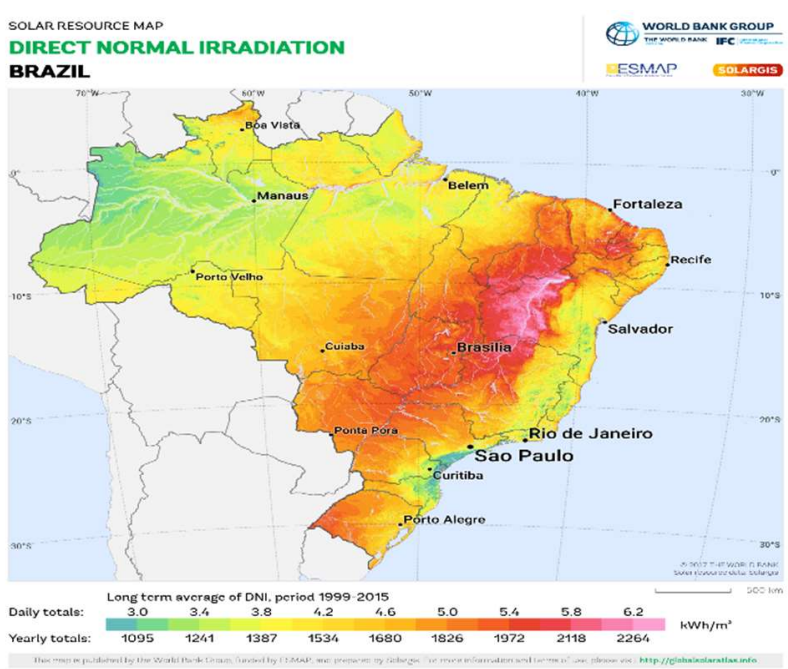

Fig. 4. Map of solar radiation of the Brazilian territory (source: https: //openei.org/wiki/Solar_and_Wind_Energy_Resource_Assessment_ (SWERA)).

According to data from SWERA (Region Radiation Databases), Figure 4, the Monte Carmelo-MG region, has an average irradiance of $5.24 \mathrm{kWh} / \mathrm{m}^{2} /$ day x 30 days.

$$
P_{f v}=\frac{E \cdot G_{s t c}}{H_{t o t} \cdot T_{D}}
$$

Where:

$\boldsymbol{E}=$ desired energy $(\mathrm{kWh} / \mathrm{month})$;

$\boldsymbol{G}_{\boldsymbol{s t c}}=$ constant $\left(1 \mathrm{kWh} / \mathrm{m}^{2}\right)$;

$\boldsymbol{H}_{\text {tot }}=$ irradiation $\left(\mathrm{kWh} / \mathrm{m}^{2} /\right.$ day x 30 days $)$;

$\boldsymbol{T}_{\boldsymbol{D}}=$ performance ratio (it is between 0.75 and 0.85 ).

Using the above formula to supply the demand of $16,359.75$ $\mathrm{kWh} /$ month through the photovoltaic system, the designer arrives through this data in the power of the system for compensation of $131 \mathrm{kWp}$, thus, a system of $72.6 \mathrm{kWp}$ will be installed for the solar energy system and the remaining $60 \mathrm{~kW}$ needed to fill the demand will be completed by the biogas system.

Table III. - Technical data for photovoltaic modules

\begin{tabular}{|l|c|}
\hline \multicolumn{1}{|c|}{ Technical Data } & Technical specification \\
\hline Model & CS6U-330P \\
\hline Nominal Max. power (Pmax) & $330 \mathrm{~W}$ \\
\hline Opt. Operating Voltage (Vmp) & $37.2 \mathrm{~V}$ \\
\hline Opt. Operating Current (Imp) & $8.88 \mathrm{~A}$ \\
\hline Open Circuit Voltage (Voc) & 45.6 \\
\hline Short Circuit Current (Isc) & $9.45 \mathrm{~A}$ \\
\hline Module Efficiency & $16.97 \%$ \\
\hline
\end{tabular}

To calculate the number of modules that will be used in the project, Table III, the following formula is used:

$$
N_{\text {mod }}=\frac{P_{f v}}{\frac{P_{m o d}}{1000}}
$$

Where:

$\boldsymbol{N}_{\text {mod }}=$ Number of modules (n)

$\boldsymbol{P}_{f v}=$ System power $(\mathrm{kWp})$

$\boldsymbol{P}_{\text {mod }}=$ Power of the module $(\mathrm{Wp})$

In order to calculate the inverter, it was dimensioned according to the power calculated by the plates, so, considering that the nominal power of the inverter could be $33 \%$ lower than the calculated value of the PV modules, the chosen inverter power was determined according to the table IV.

Table IV. - Investor Technical Data

\begin{tabular}{|l|c|}
\hline \multicolumn{1}{|c|}{ Technical Data } & Technical specification \\
\hline Model & TRIO-27.6-TL-OUTD \\
\hline Rated AC power & $27600 \mathrm{~W}$ \\
\hline AC Voltage Range & $320 \ldots 480 \mathrm{~V}$ \\
\hline MPPT & 2 \\
\hline Maximum AC Output Current & $45.0 \mathrm{~A}$ \\
\hline Short Circuit Current (Isc) & $9.45 \mathrm{~A}$ \\
\hline Rated Output Frequency & $50 \mathrm{~Hz} / 60 \mathrm{~Hz}$ \\
\hline
\end{tabular}

\section{SOFTWARE ANALYSIS}

\section{A. Analysis through PVsyst software}

Regarding the project design of the photovoltaic system, PVsyst software was used to evaluate the solar energy potential of the project site, figures 6 and 7, so that the energy generated during the year and its months of higher production can be verified.

The data of the photovoltaic generators were implemented in the system according to table III and the inverters according to table IV. A total of 220 modules with a power of $330 \mathrm{Wp}$ were used, together they formed a $72.6 \mathrm{kWp}$ system, according to Figure 5.

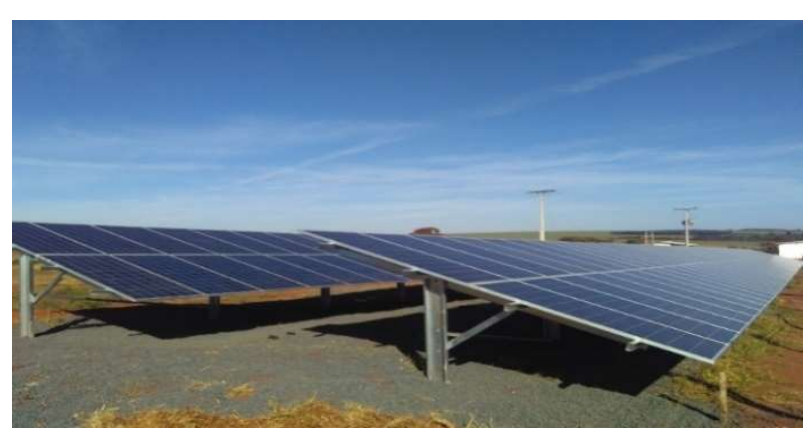

Fig. 5. Image taken from the photovoltaic plant in the farm, power of $72.6 \mathrm{kWp}$.

In Figure 6, the columns with a purple color zone, shows the loss of the collection during the months of the year, the green part and the loss of the system during the year in $\mathrm{kWh} / \mathrm{kWp} /$ day and the wine color represents the energy that will be useful. 


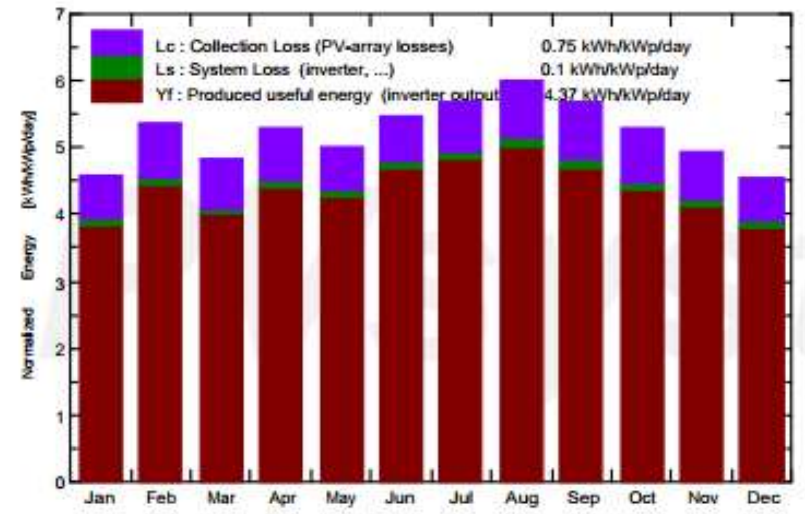

Fig. 6. Image on simulation in software Pvsyt of annual energy production from the sun.

The following table contains the simulation data in the PVsyst software throughout the year as a way of demonstrating the variation of the radiation and climatic conditions:

\begin{tabular}{|l|c|c|c|c|c|c|c|c|}
\hline & $\begin{array}{c}\text { GlobHor } \\
\mathrm{kWh} / \mathrm{m}^{2}\end{array}$ & $\begin{array}{c}\text { DiffHlor } \\
\mathrm{kWW} / \mathrm{m}^{2}\end{array}$ & $\begin{array}{c}\mathrm{T} \text { Amb } \\
{ }^{\circ} \mathrm{C}\end{array}$ & $\begin{array}{c}\text { Globinc } \\
\mathrm{kWh} / \mathrm{m}^{2}\end{array}$ & $\begin{array}{c}\text { GlobEff } \\
\mathrm{kWh} / \mathrm{m}^{2}\end{array}$ & $\begin{array}{c}\text { EArray } \\
\text { MWh }\end{array}$ & $\begin{array}{c}\text { E_Grid } \\
\text { MWh }\end{array}$ & PR \\
\hline January & 151.6 & 89.43 & 22.71 & 142.2 & 138.1 & 8.90 & 8.70 & 0.839 \\
February & 153.2 & 71.69 & 22.77 & 149.6 & 146.0 & 9.25 & 9.03 & 0.828 \\
March & 145.8 & 65.64 & 22.52 & 150.0 & 146.4 & 9.26 & 9.05 & 0.827 \\
April & 142.4 & 60.35 & 21.70 & 158.4 & 154.9 & 9.86 & 9.64 & 0.834 \\
May & 130.9 & 51.29 & 20.02 & 155.3 & 152.0 & 9.84 & 9.63 & 0.850 \\
June & 131.0 & 36.00 & 18.54 & 164.4 & 161.2 & 10.46 & 10.24 & 0.854 \\
July & 142.1 & 39.53 & 18.61 & 176.0 & 172.8 & 11.16 & 10.92 & 0.851 \\
August & 160.7 & 46.34 & 20.22 & 186.3 & 182.9 & 11.61 & 11.35 & 0.835 \\
September & 160.4 & 64.20 & 21.52 & 170.7 & 166.9 & 10.52 & 10.28 & 0.826 \\
October & 164.4 & 80.16 & 23.15 & 163.6 & 159.2 & 10.12 & 9.89 & 0.829 \\
November & 157.0 & 72.81 & 21.87 & 148.1 & 143.9 & 9.21 & 9.00 & 0.833 \\
December & 152.4 & 84.77 & 22.32 & 140.8 & 136.7 & 8.83 & 8.63 & 0.840 \\
\hline Year & 1791.8 & 762.21 & 21.32 & 1905.4 & 1861.0 & 119.01 & 116.36 & 0.837 \\
\hline
\end{tabular}

\begin{tabular}{|c|c|c|c|c|}
\hline \multirow[t]{4}{*}{ Legends: } & GlobHor & Horizontal global irradiation & GlobEff & Effective Global, corr. for IAM and shading \\
\hline & DiffHHor & Horizontal diffuse irradiation & EArray & Effective energy at the output of the array \\
\hline & TAmb & Ambient Temperature & E_Grid & Energy injected into grid \\
\hline & Globlinc & Global incident in coll. plane & PR & Performance Ratio \\
\hline
\end{tabular}

Fig. 7. Data collected from the Pvsyt software, a result of the simulation of the project implemented at the Sabia farm.

In figure 7, the first column refers to the horizontal global irradiance represented in $\mathrm{kWh} / \mathrm{m}^{2}$, in the second horizontal diffuse irradiance $\mathrm{kWh} / \mathrm{m}^{2}$, the third average ambient temperature $\mathrm{C}^{\mathrm{o}}$ /month, in the fourth flat global incidence in $\mathrm{kWh} / \mathrm{m}^{2}$, in the fifth global effect from shading in the sixth and the energy generated at the output of the system, seventh energy injected into the grid, and lastly the eighth column shows the efficiency of the system in each month.

\section{B. Analysis through Homer Pro software}

For each energy source was entered the cost value for each $1 \mathrm{~kW}$ produced, so it was simulated in the software Homer Pro, to know the value of energy over a year. In table V, is the cost of $1 \mathrm{~kW}$ for energy source through the biogas. On the other hand, Table VI shows the value of $1 \mathrm{~kW}$ for photovoltaic energy source.

Table V. - Input value of biogas source for Homer software.

\begin{tabular}{|c|c|c|c|c|}
\hline $\begin{array}{c}\text { Capacity } \\
(\mathrm{kW})\end{array}$ & Capital (\$) & $\begin{array}{c}\text { Replacement } \\
(\$)\end{array}$ & $\begin{array}{c}\text { O\&M } \\
(\$ / \text { op.hr })\end{array}$ & $\begin{array}{c}\text { Size } \\
(\mathrm{kW})\end{array}$ \\
\hline 1 & $\mathrm{R} \$ 3,000.00$ & $\mathrm{R} \$ 0.0$ & $\$ 0.53$ & $0-95$ \\
\hline
\end{tabular}

Table VI. - Input value of photovoltaic source for Homer software.

\begin{tabular}{|c|c|c|c|c|}
\hline $\begin{array}{c}\text { Capacity } \\
(\mathrm{kW})\end{array}$ & Capital (\$) & $\begin{array}{c}\text { Replacement } \\
(\$)\end{array}$ & $\begin{array}{c}\text { O\&M } \\
(\$ / o p . h r)\end{array}$ & $\begin{array}{c}\text { Size } \\
(\mathrm{kW})\end{array}$ \\
\hline 0.330 & $\mathrm{R} \$ 1,062.50$ & $\mathrm{R} \$ 0.0$ & $\$ 10.00$ & $0-72$ \\
\hline
\end{tabular}

The following graph represents the simulation of energy sources over a year, i.e. comparing annual production and energy cost, using data from tables V and VI, the input data is the cost of $\mathrm{kW}$, cost of investment and maintenance over 25 years.

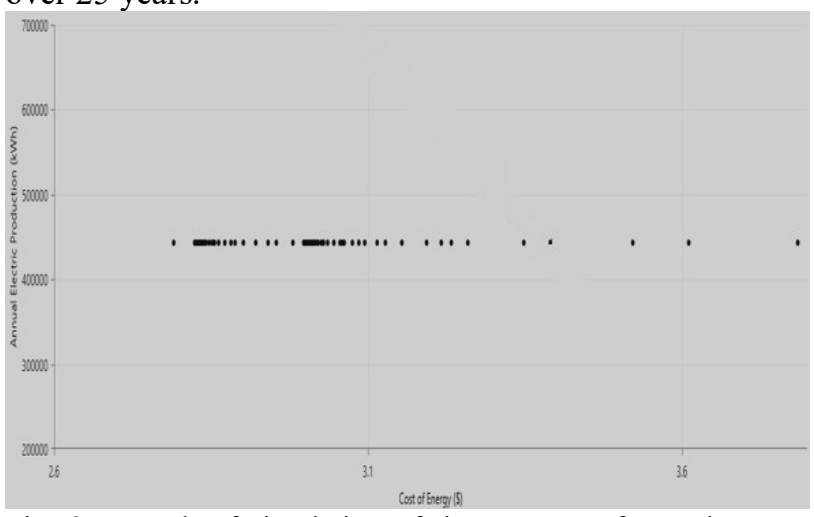

Fig. 8. Result of simulation of the Homer software between annual production of the two energy sources (biogas and photovoltaics) and cost of energy.

\section{Economic viability}

Figure 9 shows a graph represented over 25 years, the return on investment in comparison with the cost of implantation of both biogas and photovoltaic. In the cost column shows the value of the project for implantation of both biogas that is $\$ 500,000.00$, and photovoltaic that is $\$$ $350,000.00$. In another column, return, refers to the return on investment over 25 years of operation.

$$
\text { - Photovoltaic } \quad \text { Biogas }
$$

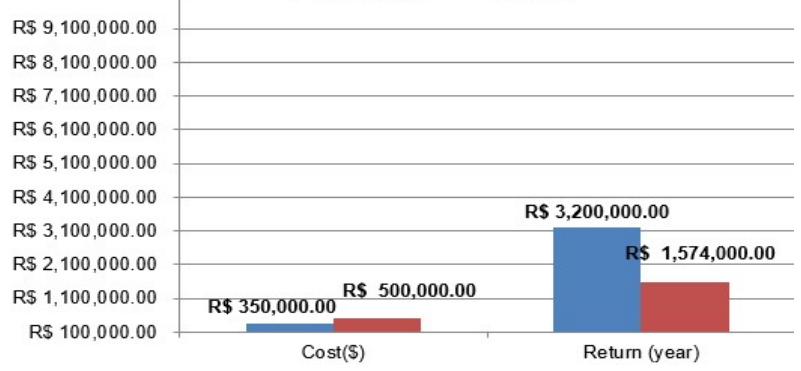

Fig. 9. Results of comparative analytical calculations between different energy sources such as biogas and photovoltaic, and their respective cost and return over 25 years.

\section{Conclusion}

With the scarcity of natural resources, current generations of energy have become unviable. Therefore, the concept of a hybrid system with a view to decentralization and diversification of the energy matrix, presents itself as an opportunity, both for energy supply and for the impacts. In view of the improvement in the quality of electric power in rural areas, the alternative sources emerged as a solution to the problems encountered (such as unstable distribution networks and voltage drops). Thus, through calculations and simulations, the functionality of the system was demonstrated, as well as its feasibility and profitability through isolated distributed generation. Through this case 
study, an initial investment of R $\$ 500.000,00$ for biogas and $\mathrm{R} \$ 350,000.00$ could be applied, 00 for photovoltaic and to have over 25 years we have a return of $\mathrm{R} \$ 3,200,000.00$ for biomass and R $\$ 1,574,100.00$ for solar energy. Therefore, it would avoid spending on upgrading distribution networks, causing lower environmental impacts from current energy sources, and energy quality would increase significantly, and return on investment would be rapid and secure.

\section{Acknowledgements}

The authors would like to thank Federal University of Uberlândia (UFU) for the opportunity of this research. We also thank Brazilian Sponsoring Agencies, CAPES Coordination of Improvement of Higher Education Personnel of the Ministry of Education, CNPq - National Council of Scientific and Technological Development of the Ministry of Science and Technology and FAPEMIG Foundation of Research Assistance of Minas Gerais State.

\section{References}

[1] Souza, Samuel Nelson Melegari de. Manual De Geração De Energia Elétrica a Partir Do Biogás No Meio Rural. 2016. 47 f. Tese (Manual) - Curso de Engenharia de Energia na Agricultura, Universidade Estadual do Oeste do Paraná, Cascavel, 2016.

[2] Zhang Yanning, Kang Longyun and Cao Binggang, "Renewable Energy Distributed Power System With Wind Power and Biogas Generator", IEEE, School of Electric Power, South China University of Technology, Guangdong key laboratory of Clean energy technology, Guangzhou China, Vol. 1, pp. 1-6.

[3] Niloy Chandra Saha, Shuvajyoti Acharjee, and Md. Abu Shahab Mollah, "Modeling and performance analysis of a Hybrid Power System", IEEE,Khulna University of Engineering \& Technology, Khulna, Bangladesh, Vol. 1, pp. 1-6.
[4] Edval Luiz Batista dos Santos and Geraldo de Nardi Junior, "Produção de biogás a partir de dejetos de origem animal", tekhne e logos, tecnologia em agronegócio da faculdade de tecnologia de Botucatu-SP, Brasil, vol. 4, Agosto 2013, pp. 1-11. [5] Rita Maria Bedran Leme Gaspar, "Utilização de Biodigestores em Pequenas e Médias Propriedades Rurais com Ênfase na Agregação de Valor: Um Estudo de Caso na Região de Toledo-PR", Programa de Pós-Graduação em Engenharia de Produção e Sistemas, Universidade Federal de Santa Catarina, Brasil, vol. 1 pp. 1-119.

[6] Cleber Aimoni Marques, "Microgeração de Energia Elétrica Em Uma Propriedade Rural Utilizando Biogás Como Fonte Primária de Energia Elétrica", Programa de Pós-Graduação Stricto Sensu Em Energia Na Agricultura - Nível Mestrado, Universidade Estadual do Oeste do Paraná, Brasil, vol. 1, Janeiro 2012, pp. 1-91.

[7] Naubert Zanoni \& Vania Elisabete Schneider, "Análise da Viabilidade da Implantação de um Sistema Híbrido para Geração de Energia Elétrica", Instituto de Saneamento Ambiental, Universidade de Caxias do Sul, Brasil, vol. 1, Abril 2018, pp. 114.

[8] Levi Santos Cidral Junior, "Treinamento em Energia Solar Fotovoltaica”, WEG, Brasil, vol. 1, Julho 2017, pp. 1-143.

[9]IUR Staff, Distributed Generation White Paper[A],2002,1,113.

[10] MA. Uyterlined, E.J.W. van Sambeek, E.D.Cross, Decentralised Generation: Development of EU Policy [A], Energy Research Center of the Netherlands,2002,10,9-69.

[11] SOUZA, J. Desempenho de um motor de combustão interna ciclo Otto operando com gás natural e biogás. 2004. 85 f. Dissertação (Mestrado em Engenharia Agrícola) - Universidade Estadual do Oeste do Paraná.

[12] CASTANHO, Biodigestores. 2008. 7 f VI Semana de Tecnologia em Alimentos - Universidade Tecnológica Federal do Paraná. 